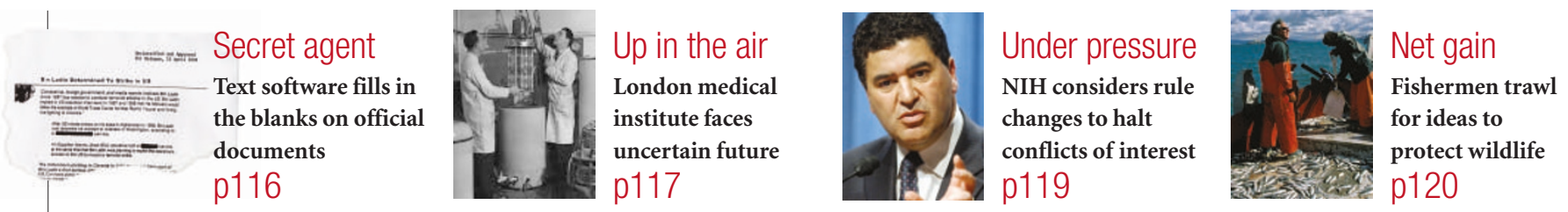

\title{
Iraqi killings prompt calls for US to evacuate weapons scientists
}

\section{Jim Giles, London}

The assassination of several of Iraq's former weapons scientists has hit US plans to employ them to help rebuild the war-torn country. The killings, together with the deteriorating security situation in Iraq, have led some non-proliferation experts to call for the researchers to be evacuated from the country.

Between five and ten scientists have been killed in the past six months, according to a US Department of State official who runs programmes aimed at keeping former weapons scientists in employment. "The most common explanation is that they've shown an interest in working with the coalition," says the official, who declined to be identified by name and who returned from Iraq earlier this month.

Between them, the Iraqi scientists hold considerable knowledge of chemical, biological and nuclear weapons from programmes that now seem to have been defunct long before the US-led coalition invaded Iraq in March 2003. But the killings are only the latest setback in plans to redirect their knowledge and skills. Non-proliferation experts who wanted to work with Iraqi scientists were angered when initial responsibility for contacting them was given to military forces. Some scientists hid, fearing that they could be taken prisoner (see Nature 423, 371;2003).

Such independent experts have since left Iraq because of security concerns, further weakening non-proliferation efforts. And David Albright, a former nuclear-weapons inspector in Iraq, says these problems mean that attempts to keep researchers in Iraq should no longer be a priority for the US government. "They should shift the programme to getting people out," says Albright, who now heads the Institute for Science and International Security in Washington. "There are scientists with secret documents who could go to Iran or Syria."

Such a change in policy would come too late for Majid Hussein Ali, a nuclear scientist reported to be at Baghdad University. Ali was not directly involved in weapons research, but he was said to have met with US weapons inspectors. He was killed by an unknown gunman in Baghdad in February.

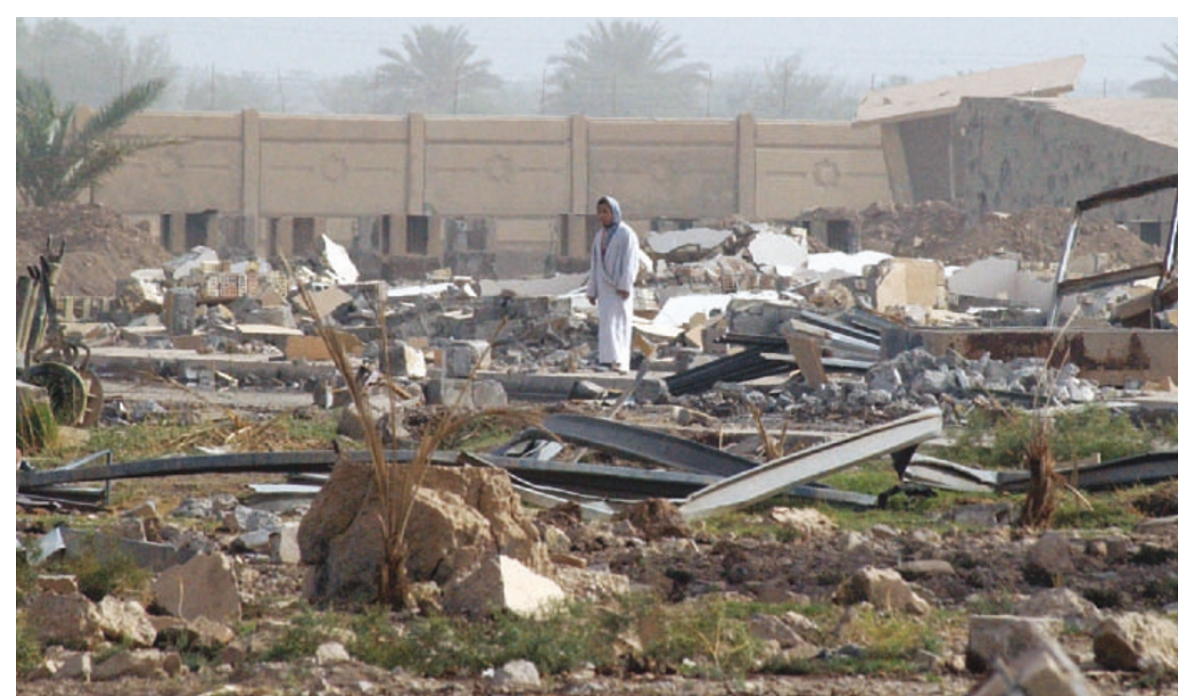

Shattered: the fall-out from the Iraq conflict is putting scientists' lives in danger.

Despite the death of Ali and other researchers, state-department officials insist that most scientists want to stay in their country. Officials have visited Iraq regularly this year, and say that they were able to win the confidence of Iraqi scientists by distancing themselves from the military activities of the coalition forces.

\section{Job creation}

The state department sought to ramp up its activities last November with a US\$2-million programme aimed at identifying former weapons researchers and finding them work in Iraq (see Nature 426, 371; 2003). Since then, officials have drawn up a list of 400 scientists, engineers and technicians who had worked on weapons research and related fields. Officials say that about 75 of these people are unaccounted for, but nearly all of the others have been located in Iraq.

The officials add that these researchers would stay in Iraq if meaningful work can be found for them. Most are currently employed in industry and academia, at least in theory. But many universities and other facilities have been closed by the invasion and subsequent insurgencies.

"They are all employed in the sense that they get a pay cheque," says the state-depart- ment official. "But some are very unhappy because they have nothing to do." The official is trying to raise $\$ 40$ million for reconstruction projects over the next three years. "We're talking to coalition partners now," he says.

State-department staff have meanwhile established an International Center for Science and Industry in Baghdad, consisting of office space that they say will be used to house Iraqi researchers who will determine how any reconstruction money will be spent.

Many Iraqi scientists have criticized schemes by outsiders to unite the country's researchers, officials at the state department acknowledge. They say that scientists felt excluded from an attempt by a largely expatriate group of Iraqi researchers to form an Iraqi academy of science (see Nature 426, $484 ; 2003)$. By ensuring that local scientists play a prominent role in the new centre, the officials hope that the facility will be accepted as legitimate by Iraqi researchers.

But Albright, who initially backed the state department's programme, is worried about what will happen to the former weapons scientists. He went to Iraq last year and helped US officials to locate many of them. Such trips ended in the autumn, as the security situation worsened. Even then, Albright says, "everyone wanted to get out". 